\title{
Epididymal contribution to male infertility: An overlooked problem
}

\author{
Salah Elbashir $^{1}$ | Yasmin Magdi ${ }^{2}$ (D) | Ayman Rashed ${ }^{3}$ | Ralf Henkel ${ }^{4,5}$ (D) | \\ Ashok Agarwal ${ }^{5}$ (i)
}

${ }^{1}$ Department of Urology, Faculty of Medicine, Benha University, Egypt

${ }^{2} \mathrm{Al}$-Yasmeen Fertility and Gynecology Center, Benha, Egypt

${ }^{3}$ Department of Urology, Faculty of Medicine, 6th of October University, Egypt

${ }^{4}$ Department of Medical Bioscience, University of the Western Cape, Bellville, South Africa

${ }^{5}$ American Center for Reproductive Medicine, Cleveland Clinic, Cleveland, $\mathrm{OH}$, USA

\section{Correspondence}

Yasmin Magdi, Al-Yasmeen Fertility and Gynecology Center, 5 Farid Nada Street, Benha 13511, Qalubyia, Egypt.

Email: Yas.magdi@hotmail.com

Funding information

No external funding was either sought or obtained for this study.

\begin{abstract}
The diagnosis and treatment of male infertility, excluding assisted conception, are limited because of, but not limited to, poor understanding of sperm post-testicular development and storage. Many may think that sperm dysfunction is only self-contained in the sperm cell itself as a result of defective spermatogenesis. However, it can also be a consequence of inadequate epididymal maturation following disorders of the epididymis. Improper epididymal functions can disturb semen parameters and sperm DNA integrity, result in high leucocyte concentrations and high numbers of immature germ cells and debris or even cause idiopathic infertility. To date, the data are limited regarding critical markers of sperm maturation and studies that can identify such markers for diagnosis and managing epididymal dysfunction are scarce. Therefore, this article aims to draw attention to recognise a disturbed epididymal environment as a potential cause of male infertility.
\end{abstract}

\section{KEYWORDS}

Epididymal anomalies, Epididymal dysfunction, Epididymal toxicity, Epididymis

\section{1 | INTRODUCTION}

Spermatozoa are produced in the seminiferous tubules of the testes via a complex, highly regulated differentiation process called spermatogenesis. Testicular spermatozoa are nonfunctional and lack the ability to naturally fertilise an oocyte (Jones, 1999; Tulsiani \& Abou-Haila, 2012; Xu, Washington, \& Hinton, 2014; Zhou, De luliis, Dun, \& Nixon, 2018). After being released from the germinal epithelium in the process called spermiation, spermatozoa pass through tiny channels, the rete testis and the efferent ducts into the epididymis, where they undergo a complicated maturation process leading to biochemical, physiological and functional changes. During the epididymal transit, epididymal duct secretions are mixed with the testicular content to provide a specific environment in which functionally immature spermatozoa undergo multiple modifications, resulting in a functional spermatozoon that is able to successfully fertilise an oocyte (Amann, Hammerstedt, \& Veeramachaneni, 1993).
Sperm dysfunctions are recognised as the most significant cause of male infertility (Cornwall \& Horsten, 2007) and many may think that sperm dysfunction is only self-contained in the sperm cell itself as a result of defective spermatogenesis. However, it can also be the result of an inadequate epididymal maturation process due to improper epididymal function (Kathrins, 2017).

Understanding of post-testicular sperm development and maturation including epididymal storage remains limited, which can significantly influence the diagnosis and treatment of male infertility, excluding assisted conception. Since the most dramatic modifications affecting spermatozoa have been localised in the epididymis, it is necessary to recognise these maturation events as a significant cause of male infertility (Jones \& Dacheux, 2007). Therefore, the purpose of this review is to focus on the effects of epididymal disorders on sperm quality and male infertility. This systematic review may also provide an explanation for abnormal spermiogram values of infertile men as well as cases of idiopathic male infertility. 


\section{2 | MATERIALS AND METHODS}

\section{1 | Literature search}

A computerised literature search was performed independently by three reviewers (SB, YM and AR) in PubMed, MEDLINE, EMBASE, CENTRAL and randomised controlled trials (RCT) registries, covering the period from 1970 to October 2019, aiming to identify all available studies investigating the epididymal disorders in human or animals and its effect male infertility. Further manuscripts published before 1970 were reviewed for specific topic areas and included as appropriate.

For this purpose, the free text search key words (epididymis, post-testicular sperm maturation, sperm maturation, sperm storage, epididymal anomalies and epididymal toxicity, combined with infertility, male factor, sperm dysfunction, inadequate events and semen parameters) were used. Additionally, the citation lists of all relevant publications and review articles were hand-searched. No language limitations were applied.

\section{2 | Study selection}

Articles that were published in any language and that focused on the specific topics described above were included. Additional papers cited in the primary reference were also taken into account.

\section{3 | MECHANISM OF FUNCTION}

The epididymis is a long, complex, highly convoluted tubule connected to the rete testis by efferent ducts and downstream to the vas deferens. The adult epididymis reaches over an estimated length of 5-7 m in men (O'Hara, Welsh, Saunders, \& Smith, 2011; Sullivan, 2004), $1 \mathrm{~m}$ in mice (Takano, Abe, \& Ito, 1981), $3 \mathrm{~m}$ in rats (Turner, Gleavy, \& Harris, 1990) and $80 \mathrm{~m}$ in horses (Maneely, 1959). Despite differences in the length of the epididymal duct, the mammalian epididymis is generally divided into four distinct anatomical regions: initial segment, caput (head), corpus (body) and cauda (tail), as early described by Benoit, 1926 (Figure 1).

At day (E) 14.5, the upper reproductive tract consists of three distinct systems: the Wolffian duct, the mesonephric tubules and the Mullerian duct. At E15, the anterior portion of the Wolffian duct adjacent to the testis elongates and folds into the epididymis, the middle portion remains as a simple tube, to form the vas deferens, while the posterior portion dilates, elongates cranially and forms a distinct diverticulum. The mesonephric tubules fuse with the Wolffian duct and are believed to become the efferent ducts, which connects between the rete testes and epididymis (Barsoum \& Yao, 2006). The epididymis further changes from a simple straight tube to a highly convoluted structure through a complex coordinated succession of molecular and morphogenic events (Joseph, Yao, \& Hinton, 2009). For example, in the mouse, the Wolffian duct is approximately $1 \mathrm{~mm}$ at embryonic day 14 (E14), which means it must elongate 1,000
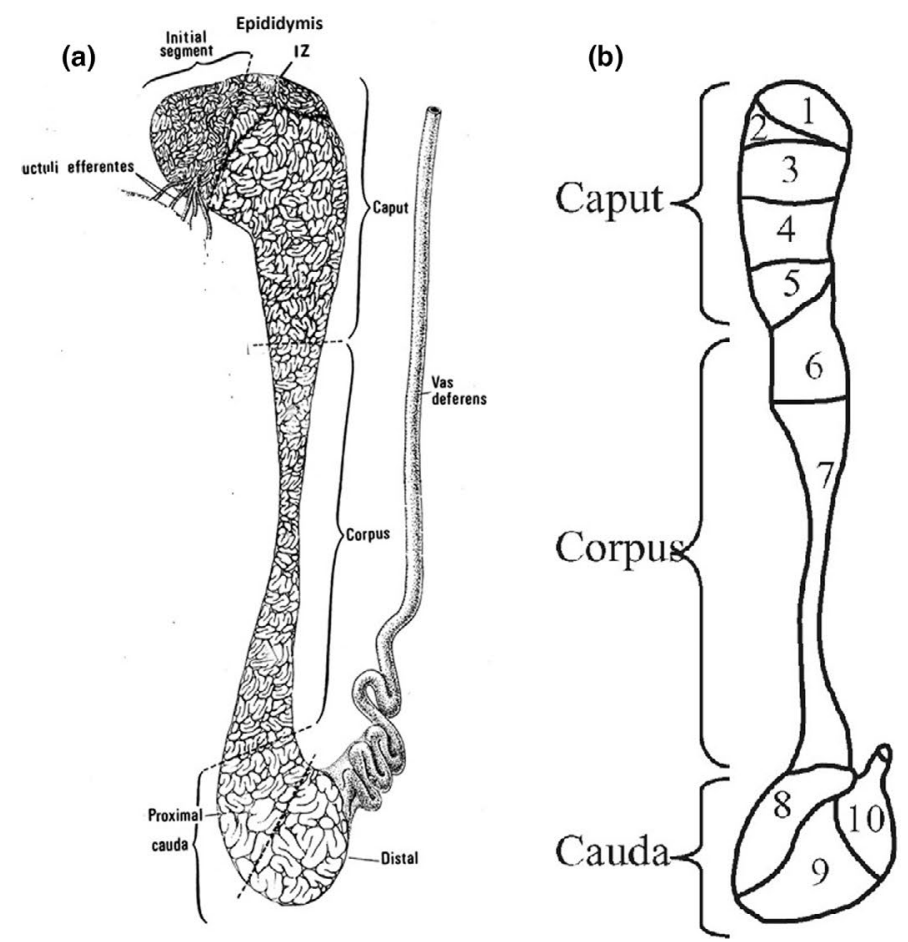

(c)

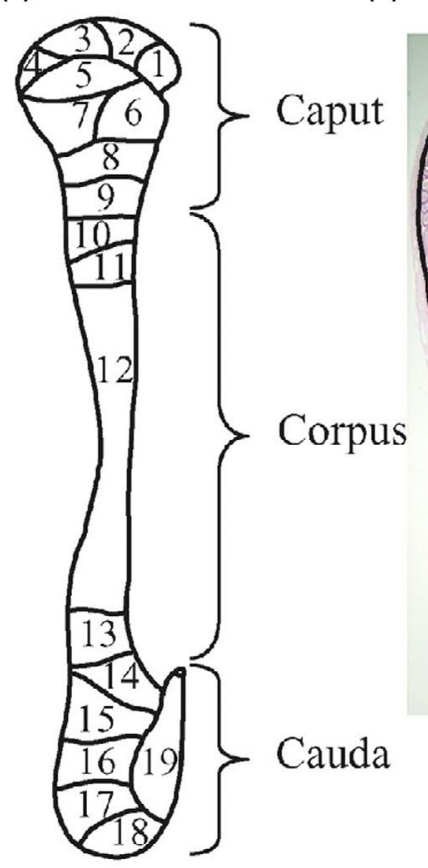

(d)

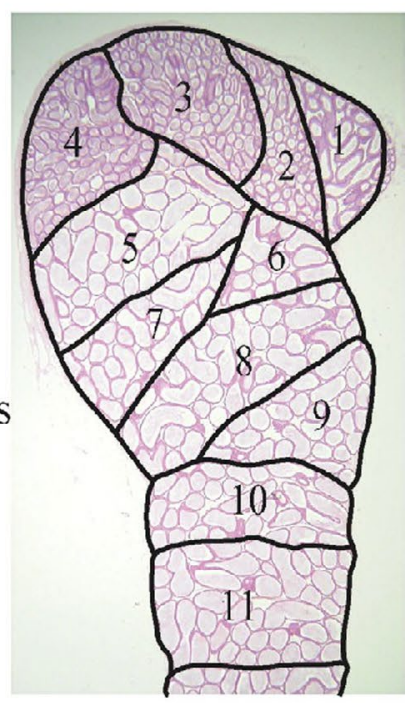

FIGURE 1 Segmental structure of the epididymis. (a) Normal cross section the ductuli efferentes, the epididymis and vas deferens. The regionalisation of the epididymis, that is, the initial segment, intermediate zone, caput, corpus and proximal and distal cauda, are indicated. (b) Typical schematic patterns of mouse and (c) rat epididymal segmentation. (d) Histological appearance of segments 1-11, which comprise the rat caput epididymis and proximal corpus. (a) Reprinted with permission from (Robaire et al., 2006), and (b), (c) and (d) Reprinted with permission from (Jelinsky et al., 2007) 
times its length within a defined space (Domeniconi, Souza, $\mathrm{Xu}$, Washington, \& Hinton, 2016). These modifications are not limited to a simple elongation event; the epididymal duct starts expansion, coiling and segmentation at E16.5 to morph from a straight tube to an elaborately, convoluted, segmented tube. During this period, the efferent ducts have also initiated coiling (Snyder et al., 2010). From E16.5 to postnatal Day 1 (P1), coiling resumes in the efferent ducts and moves caudally from the initial segment to the cauda of the developing epididymis. These modifications end with the three-dimensional coiled epididymis that is comprised of several distinctly functional segments. In the human, the epididymis transforms its morphology to form a 6-m-long duct that is coiled and packed into a three-dimensional organ of $\sim 10 \mathrm{~cm}$ in length (Hinton et al., 2011; Murashima, Xu, \& Hinton, 2015).

The epididymal tube is folded into a highly organised structure comprised of many discrete, intraregional segments that are structurally and functionally delineated by connective tissue septa (Turner, Bomgardner, Jacobs, \& Nguyen, 2003). Each segment is considered as an individual 'organ', creates its unique specialised luminal microenvironment known as 'segment-specific microenvironment', possessing its own overlapping genes, regulatory proteins and signal transduction pathways within distinct epithelial cell types (Cornwall, 2009). Thus, we can consider the epididymis a series of small organs placed side by side (Domeniconi et al., 2016). The cells lining these segments do not function in isolation but communicate with neighbouring and/or downstream cells via paracrine mechanisms. Ordered and compartmentalised alternation in a series of individual epididymal microenvironments results in sperm functional maturation leading to changes in morphology, motility, biochemistry, permeability, concentration and metabolism (Cosentino \& Cockett, 1986).

Considering that spermatozoa are translationally silent, dynamic modification of the proteome of spermatozoa via uptake, repositioning and post-translational modification of a variety of protein and small noncoding RNA promotes the gradient of increasing fertility in the sperm population held therein (Liu \& Liu, 2015; Paunescu et al., 2014; Skerget, Rosenow, Petritis, \& Karr, 2015). Several hundred proteins are secreted by the epididymal epithelium into the epididymal lumen. Moreover, extracellular vesicles called epididymosomes contain proteins (Nixon et al., 2019), small noncoding RNAs (Reilly et al., 2016; Sharma et al., 2018) and lipids (Girouard, Frenette, \& Sullivan, 2011) that are delivered to maturing spermatozoa. Not only protein and chemical composition vary along the duct, but also their concentration. For example, the protein concentration ranges from 2 to $4 \mathrm{mg} / \mathrm{ml}$ in the initial segment of the epididymis, peaks to a maximum of $50-60 \mathrm{mg} / \mathrm{ml}$ in the distal caput and returns to $20-30 \mathrm{mg} / \mathrm{ml}$ in more distal regions of the organ (Belleannee et al., 2011; Fouchecourt, Metayer, Locatelli, Dacheux, \& Dacheux, 2000). These variations in protein concentration are associated with changes in water content of the fluid as determined by changes in sperm concentration between the testis, the deferent duct and epididymis. From the rete testis to the deferent duct, the sperm concentration raises from $10^{8}$ to $10^{9}$ spermatozoa $/ \mathrm{ml}$, with a maximum in the first part of the epididymis. Although much of the fluid leaving the testicle is resorbed within the efferent ducts, water reabsorption continues at a low level up to the epididymis (Levine \& Marsh, 1971; Wong \& Yeung, 1978). A family of small, hydrophobic proteins termed aquaporins acts as water channels that facilitates rapid water movement across cell membranes via transepithelial movement of $\mathrm{Na}^{+}, \mathrm{Cl}^{-}, \mathrm{HCO}^{3-}$ and results also in significant modifications in the ionic composition of the lumen fluid along the epididymal tubule (Agre et al., 2002; Verkman \& Mitra, 2000).

The epididymal epithelium comprises different epithelial cell types including mainly principal cells $(\sim 85 \%)$, narrow cells (found only in the initial segment), basal cells, accompanied by other specialised cells including apical, narrow, clear and halo cells (intraepithelial leucocytes; Breton, Ruan, Park, \& Kim, 2016). These cell types distribute in a segment-specific manner to serve different functions such as secretion, absorption, and endocytosis, acidification of the luminal fluid, immune defence, phagocytosis, and production of antioxidants (Hermo \& Robaire, 2002). Tight, adhered junctional complexes between epithelial cells are found at their luminal surface (Dubé, Chan, Hermo, \& Cyr, 2007) maintaining the integrity of the epididymal epithelium and form a protective blood-epididymis barrier (Cornwall, 2009). This blood-epididymis barrier has several functions, including regulation of epididymal lumen composition via selective transport of ions, solutes and macromolecules through the epithelium, protection of spermatozoa from immune system and bacterial attacks (Dubé \& Cyr, 2012).

Epididymal structure and function were shown to be primarily dependent on testosterone through genomic and nongenomic mechanism of action. Testosterone enters the epididymis via two distinct routes: (a) it enters through the efferent ducts after leaving the rete testis (b) and also enters the epididymal epithelial cells by passive diffusion (Robaire \& Hamzeh, 2011). The effects of testosterone withdrawal and replacement have been extensively studied through many experimental models. Neither cell survival nor cell division was affected by androgen administration or withdrawal (Hamzeh \& Robaire, 2011). Human hypogonadism associated with testosterone deficiency is also correlated with impaired sperm epididymal maturation (Schorr-Lenz et al., 2016). Hypogonadism results in an accelerated sperm transit time through the epididymis, loss of sperm motility and reduced ability of the cauda epididymis to store spermatozoa (Robaire \& Hinton, 2015). Moreover, removing both testes (bilateral orchidectomy) results in a loss not only of androgens, but also a $25 \%$ decrease in the weight of the epididymis. This treatment is often followed by androgen replacement, showing a partial restore of the weight of the epididymis (Brooks, 1987; Cheuk, Leung, Lo, \& Wong, 2000; Fan \& Robaire, 1998).

Not only androgens, but there is also evidence that the epididymis of mammals is dependent on oestrogen (Filippi et al., 2002; Snyder, Small, Li, \& Griswold, 2009). Oestrogen is mainly produced by germ cells, presenting a relatively high concentration in rete testis fluid. Unlike the caput through cauda regions of the epididymis, androgen replacement following rete testis ligation or castration does not rescue epithelial morphology of the initial segment regions 
(Chauvin \& Griswold, 2004; Fawcett \& Hoffer, 1979). Meistrich, Hughes, and Bruce (1975) were the first reporting a decrease in sperm transit time with exposure to oestrogen; however, the dosage was very high. Another interesting study by Hess et al., 1997 further demonstrated that oestrogen regulates the reabsorption of luminal fluid in the head of the epididymis. Many other studies have shown that oestrogen regulates epididymal contractility by upregulating the calcium-sensitising RhoA/ROCK pathway in epididymal smooth muscle (Fibbi et al., 2009), which maintains epididymal sensitivity to oxytocin and endothelin-1 (Filippi et al., 2002, 2005; Vignozzi et al., 2010).

Sperm cells possess unique surface proteins, which are potential stimuli of the immune system, with the risk of inducing autoantibodies and consequently male infertility (Witkin, Jeremias, Bongiovanni, \& Munoz, 1996). However, there is a special need for efficient immune response to pathogens. Thus, a finely tuned balance between efficient immune responses to pathogens and strong tolerance to sperm cells is essential requirement to maintain epididymal normal function. The mammalian epididymal immune system is rather different from that of the testis. Firstly, epididymitis, the inflammation of epididymis caused by the immune response to pathogens, is largely more common than orchitis and the latter very often leaks to epididymo-orchitis while the reverse is not that frequent. Secondly, acute epididymitis is essentially induced by retrograde invasion of urethral bacterial pathogens in sexually transmitted disease cases, while orchitis is more frequently due to blood-transmitted pathogen. Moreover, the incidence of epididymal tumours is about 50 times less than that of the testis and $80 \%$ of epididymal cancers are benign (Yeung, Wang, \& Cooper, 2012). This suggests that despite their luminal connection through the efferent ducts, the immune regulatory surveillance that controls the seminiferous and epididymal tubules is probably different and that the caput could be a control point limiting the proliferation of ascending pathogens (Guiton, Henry-Berger, \& Drevet, 2013).

The epididymal immune balance must be set and maintained towards spermatozoa. The first level of protection is the blood-epididymis barrier, either by preventing sperm antigens from escaping the duct or by impeding immune cells from infiltrating into the lumen. The second level of protection against immune responses to spermatozoa depends on the immune cells populating the tissue. Data from experimental animal models showed that mechanisms underlying infectious disease and inflammatory conditions are interrelated with autoimmune phenomena (Hedger, 2011). Furthermore, mouse bacterial epididymitis models point to the importance of the host response to infection in causing damage (Michel et al., 2016). This is prompting us to consider the value of anti-inflammatory or immunomodulatory therapy in addition to standard antibiotic treatment. Therefore, immune-based male infertility should be considered in a broader context, beyond the presence of antisperm autoantibodies, as it is commonly defined.

In the human, spermatozoa migrate through the epididymis in an estimated period of 2-4 days (Jones \& Dacheux, 2007). However, some spermatozoa may take a period of 12 days, and some other transit through the duct in only 1 day (Johnson \& Varner, 1988; Rowley, Teshima, \& Heller, 1970), depending on the ratio of epididymal sperm reserves and testicular sperm output. Therefore, there is a considerable heterogeneity of the age of spermatozoa present in the cauda epididymis reflecting the asynchronous nature of sperm maturation (Jones \& Dacheux, 2007). Upon sperm maturation, the spermatozoa are stored within the cauda epididymis in a quiescent state until ejaculation (Zhou et al., 2018). Although the lumen of the cauda epididymis has the capacity to maintain spermatozoa viable and in a potentially fertilising condition at high sperm concentrations up to up to 7-8 weeks after the last ejaculation (Bedford, 1994), a period of 3-4 days is estimated to be optimum storage period for spermatozoa within the cauda. Due to a relative small storage capacity of its poorly differentiated cauda, a decline in semen quality is observed after 10 days of abstinence (Moore, 1998).

Besides the well-known role of the epididymis in sperm maturation and preservation, an additional function has been suggested to provide a site for elimination of old or deteriorated spermatozoa (Cornwall, 2009). However, there is no sufficient evidence to support this function (Robaire, Hinton, \& Orgebin-Crist, 2006). Any absence or depletion in the epididymal functions can be a significant factor in male infertility (Turner, 2008).

\section{4 | EPIDIDYMAL ANOMALIES}

The epididymis connects the efferent ducts to the vas deferens and is normally attached to the posterolateral surface of the testis through the cranial pole. The attachment of epididymis to the testis takes place medially through the epididymo-testicular connective tissue and distally by the caudal connective tissue and the epididymal fat pad. As described, the epididymis is generally divided into four regions: initial segment, caput (head), corpus (body) and cauda (tail). Embryologically, the epididymis develops from the cranial part of the mesonephric (Wolffian) duct under the influence of androgens produced by the differentiated Leydig cells. At birth, the epididymis consists mainly of mesenchymal tissue. The epididymis then elongates and convolutes till puberty, to form a fully differentiated, highly tortuous tubule lined by epithelial cells. Structural epididymal abnormalities, either acquired or congenital, lead to a disturbed epididymal microenvironment, which ultimately causes infertility (Singh, Hamada, Bukavina, \& Agarwal, 2012). For the practising urologist, it is important to identify epididymal deformities so that adequate treatment can be instituted promptly.

Epididymal anomalies (Figure 2) have been frequently associated with cryptorchidism (Favorito, Riberio Julio-Junior, \& Sampaio, 2017). However, some authors thought that this association may reflect the role of the epididymis in testicular descent. Bedford hypothesised that the regulation of normal testicular descent into the scrotum is primarily to preserve normal epididymal function (Bedford, 1978). According to the study conducted by Hadziselimovic $\&$ Herzog, 1983, the gubernaculum inserts in the epididymis and not 
FIGURE 2 (a) Agenesis of all mesonephric derivatives. (b) Nonunion between the globus major of the epididymis and the testicle. (c) Agenesis at mid-epididymis. (d) Atresia at midepididymis. (e) Agenesis or atresia at tail of epididymis. (f) Extended or looped epididymis and vas deferens. (g) Extended or looped epididymis and vas deferens: more extensive anomaly than represented in (f). (h) Epididymal cyst of globus major of epididymis. Adapted from (Kroovand \& Perlmutter, 1981) (a)

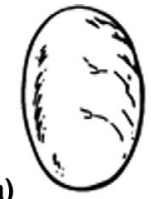

(b)

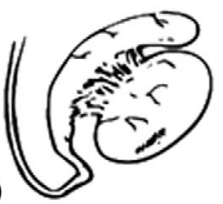

(c)
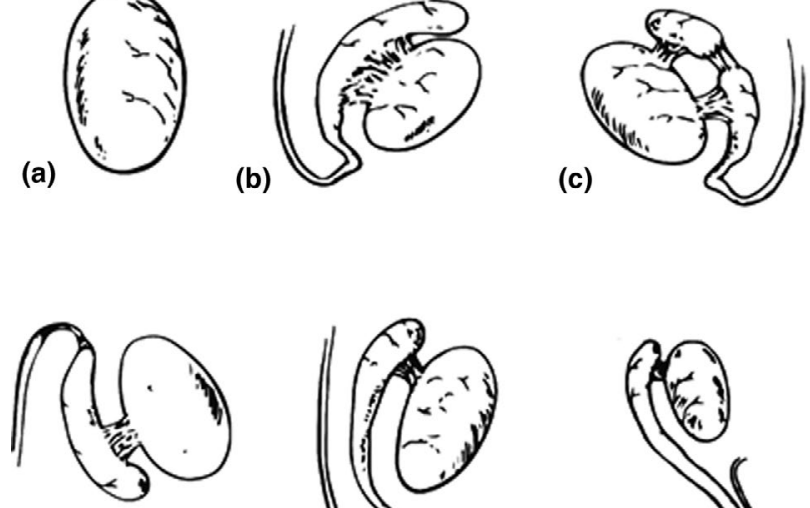

(e) (f)

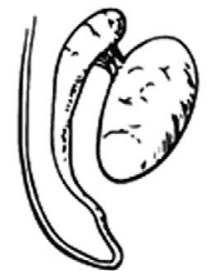

(g)

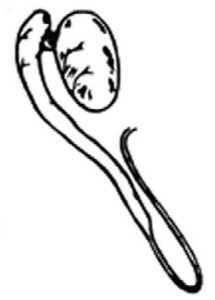

(d)

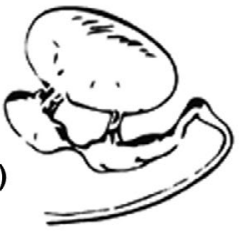

(h)

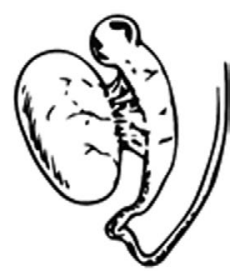

in the testis and thus drives the epididymal descent (ruling the testicular descent indirectly).

Physical deformities of the epididymis have been reported in the literature including epididymal cysts, epididymal fusional anomaly, elongated epididymis and epididymal agenesis. The most reported common anomaly is the epididymal cysts, with an incidental finding in approximately $30 \%$ of asymptomatic males. Epididymal cysts (Figure $2 \mathrm{~h}$ ) are small retention lesions of the epididymis, which contain lymphatic fluid and lined with a single layer of epithelial cells. They are usually asymptomatic that are diagnosed incidentally on physical examination or ultrasonography. They may arise from either acquired or congenital basis, perhaps arias during maturation of the mesonephric ductal system (Vohra \& Morgentaler, 1997). Patients with von Hippel-Lindau syndrome, early-onset renal cell carcinoma, polycystic kidney disease, and offspring of females exposed to diethylstilbestrol exposure in utero have an increased risk of epididymal cysts (Singh et al., 2012). If spermatozoa appear in the epididymal cysts, they are called spermatoceles (Hirsh, Dean, Mohan, Shaker, \& Bekir, 1996). The association between epididymal cysts or spermatoceles and male infertility has not yet been established (Singh et al., 2012). Surgical excision of epididymal cyst or spermatocele is only recommended for abnormally enlarged or painful. Unfortunately, the surgery almost results with epididymal injury, in which a part of epididymal tube may be damaged as a result of such surgery procedures. This may result in either a segmental damage that will affect the maturation and storage efficiency without obstruct total luminal flow through the organ or complete epididymal obstruction (Turner, 2008). Epididymal injury of the epididymis may also possibly occur in cases underwent microsurgical epididymal sperm extraction (MESA) or percutaneous sperm aspiration (PESA). Therefore, using MESA and PESA in clinical practice should be reconsidered due to the possible induced injury or obstruction.

An elongated or extended epididymis (Figure $2 \mathrm{f}, \mathrm{g}$ ) is another common epididymal defect, in which a thin, loosely attached and long looping epididymis extends distally beyond the testis into the lower inguinal canal or upper scrotum (Fahmy, 2015; Marshall \& Shermeta, 1979; Rosenberg \& Urca, 1972; Scorer \& Farrington, 1972).
In cryptorchidism, the anomaly appears most commonly, but with lesser degree of extended epididymis.

Epididymal agenesis (Figure 2a) is a rare congenital anomaly, characterised by unilateral or bilateral absence of the epididymis totally or segmentally (McCullough, Marshall, Berry, \& Detweiler, 1984). This anomaly appears secondary to a congenital Wolffian duct defect and is almost associated with unilateral or bilateral absence of the vas deferens (Badr, Motlagh, \& Sepehran, 2015). Epididymal atrophy (Figure $2 \mathrm{~d}$ ) is another anomaly, characterised by a diminished diameter and weight of the epididymal ducts due to epithelial atrophy. The epididymis appears in a scalloped form due to intraductal folding of the epithelium. It is mainly caused secondary to decreased testicular testosterone and reflects a decreased testicular spermatogenesis (Vidal \& Whitney, 2014).

Epididymal fusional anomaly, in which the epididymis fails to attach with testis, is a very rare congenital malformation and its incidence is very often higher in patients with undescended testis (Lazarus \& Marks, 1947). It has also been reported in boys who have undergone hydrocele surgery (Han \& Kang, 2002). It may occur at the junction of caput and the testis (Figure 2b), at the corpus, in the distal epididymis at the junction of the tail and vas deferens (Scorer \& Farrington, 1972; Marshall \& Shermeta, 1979; Scorer \& Lythgoe, 1961).

\section{5 | EPIDIDYMAL TOXICITY}

The functional diversity and the complexity of the epididymis render it, directly or indirectly, highly suitable to chemical disturbance. Some chemical compounds can induce epididymal toxicity leading to histological changes throughout the epididymal tube. Unfortunately, the influence of nutritional and environmental toxins on epididymal function is still overlooked (Chitra, Manogem, Vardhanan Shibu, Sebastian, \& Jayakumar, 2011).

Since the epididymis is obligatory androgen-dependent in its function, testosterone and dihydrotestosterone regulate sperm maturation and transit through the epididymal tube (Dyson \& 
TABLE 1 Some cell-specific toxicants of the epididymis

\begin{tabular}{|c|c|c|}
\hline Toxicant & Description & Effect \\
\hline $\begin{array}{l}\text { Finasteride ( Garcia } \\
\text { et al., 2012) }\end{array}$ & (Inhibitors of $5-\alpha$ reductase) & $\begin{array}{l}\text { - alterations in the proximal epididymal caput } \\
\text { - lower epithelial height and epididymal duct } \\
\text { - compromises sperm maturation } \\
\text { - affecting semen parameters and impairs fertility }\end{array}$ \\
\hline Triptolide (Huynh et al., 2000) & & $\begin{array}{l}\text { - interference with sperm maturation } \\
\text { - Cauda epididymal sperm content decreased by } 84.8 \% \text { and sperm motility } \\
\text { was reduced to zero. } \\
\text { - cauda epididymal spermatozoa exhibited severe structural abnormalities. }\end{array}$ \\
\hline $\begin{array}{l}\text { Cyclophosphamide (Trasler \& } \\
\text { Robaire, 1988) }\end{array}$ & Anticancer drug & - reduction in epididymis weight \\
\hline $\begin{array}{l}\text { Methyl chloride (MeCl) ( } \\
\text { Creasy, 2001) }\end{array}$ & Organic compound & - Epithelia I necrosis resulting in sperm granulomas \\
\hline $\begin{array}{l}\text { Vincristine ( Sonawane, Azaz, } \\
\text { Hemant, \& Liji, 2019) }\end{array}$ & $\begin{array}{l}\text { - Chemotherapy of cancer } \\
\text { - Reduces testosterone levels }\end{array}$ & $\begin{array}{l}\text { - Changes in ion concentrations of cauda and caput of epididymis with } \\
\text { changes in protein profile of the tissue }\end{array}$ \\
\hline $\begin{array}{l}\alpha \text {-Chlorohydrin (high doses) ( } \\
\text { Creasy, 2001) }\end{array}$ & Organic chemical compound & $\begin{array}{l}\text { - Inhibits fluid resorption and causes oedema of the caput resulting in } \\
\text { sperm granulomas }\end{array}$ \\
\hline $\begin{array}{l}\text { Cadmium ( Adamkovicova } \\
\text { et al., 2014) }\end{array}$ & Toxic, heavy metal & $\begin{array}{l}\text { - Reduction of epithelium. } \\
\text { - Increased epididymis weights } \\
\text { - Necrotic epithelial cells. } \\
\text { - Vasoconstriction } \\
\text { - Interstitial oedema together with mononuclear cell infiltration. }\end{array}$ \\
\hline
\end{tabular}

Orgebin-Crist, 1973). Therefore, functional disturbances in the androgen balance in blood and rete testis fluid will negatively affect the epididymis, sperm maturation and fertility (Vidal \&Whitney, 2014). In general, continued exposure to any compound that causes testosterone deficiency indirectly results in decreased epididymal weight and apoptosis of the luminal epithelium. For example, xenobiotics are toxic substances that act as endocrine disrupters that decrease testosterone synthesis and androgenic signalling, and consequently alter epididymal epithelial cell function and sperm maturation (Marty, Chapin, Parks, \& Thorsrud, 2003). Androgen receptor antagonists cause similar changes to the epididymis. Moreover, androgen deprivation due to castration, hypophysectomy, implantation of testosterone-oestradiol implants and administration of a potent Leydig cell toxicant (EDS) could result in epithelial apoptosis and decrease in epithelial cell height and epididymal tubule diameters (Zhu et al., 2000). Furthermore, testosterone deficiency in the ageing male severely affects the histology of the epididymal epithelium (Serre \& Robaire, 1998), resulting in changes in the DNA methylation pattern (epigenetic changes), altered sperm motility and retention of cytoplasmic droplets (Geyer, Kiefer, Yang, \& McCarrey, 2004). All of these alterations persist until androgen levels recover (De Grava Kempinas \& Klinefelter, 2014).

Epididymal alterations might not only be secondary to testicular disorders, but also direct pathologic effects may be another reason, Table 1. Some compounds, such as methyl chloride, alter directly the structure and function of the epididymis resulting in apoptosis and exfoliation of principal cells with increasing the epithelial height (Working, Bus, \& Hamm, 1985).

\section{6 | SEMEN PARAMETERS}

Disruption of the epididymal environment or toxic effects on spermatozoa can also occur in the absence of any histological changes in the epididymis (e.g., alterations in the luminal $\mathrm{pH}$ affect sperm maturation and storage). Semen analysis of motility, morphology, DNA fragmentation as well as leucocytes, immature germ cells and debris could reflect the epididymal performance. 


\section{1 | Sperm concentration}

Within the epididymis, the increase in the luminal sperm concentration is caused by water reabsorption via osmotic shifts, driven by transepithelial movement of $\mathrm{Na}^{+}, \mathrm{Cl}^{-}$and $\mathrm{HCO}_{3}^{-}$(Da Silva, Piétrement, Brown, \& Breton, 2006). This consequence of such water reabsorption results in a spectacular increase in the luminal sperm concentration from $10^{8}$ spermatozoa $/ \mathrm{ml}$ in the rete testis fluid to $10^{9}$ in the cauda epididymis (Dacheux \& Dacheux, 2013). The inability to reabsorb water causes dilution of caput spermatozoa, which in turn result in a decline in sperm count (Hess, 1998). Furthermore, oestrogen imbalance disturbs the reabsorption of luminal fluid in the head of the epididymis. This also causes spermatozoa to enter the epididymis diluted, rather than concentrated, resulting in declines in human sperm counts (Hess et al., 1997).

Moreover, the rate of sperm transit through the epididymal tube has an important influence on the concentration of spermatozoa and also effects the concentration of secreted or absorbed molecules important for sperm maturation (Gervasi \& Visconti, 2017). Consequently, decreased sperm transit along epididymal tubule can directly reduce the final sperm concentration stored in the cauda. Thus, the final sperm concentration may reflect both cellular mechanisms and function of the epididymis (Turner, 2008).

\section{2 | Sperm motility}

Testicular spermatozoa are usually immotile and functionally immature. Under the effect of epididymal secretions, the motility gradually increases from caput to cauda (Sullivan \& Mieusset, 2016), with considerable species-specific differences between the acquisition of motility (Dacheux \& Paquignon, 1980). In the human, spermatozoa leave the caput with sluggish and irregular motion (Mathieu et al., 1992). As spermatozoa are moving through the distal half of the corpus, qualitative changes in sperm motility, from only a faint twitch of the tail to a full vigour rapid and forward motion, are observed (Amann et al., 1993). Such motility is only analysed in vitro when epididymal spermatozoa have been diluted in a culture medium either with or without epididymal fluids (Abella, Da Costa, Guérin, \& Dacheux, 2015). However, most of the cauda spermatozoa are only in the quiescent state in vivo (Dacheux \& Dacheux, 2013).

In the human, about $20 \%-40 \%$ of ejaculated spermatozoa are immotile (Ola, Afnan, Papaioannou, Sharif, \& Bjorndahl, 2003). Similarly, about $30 \%-40 \%$ of cauda epididymis spermatozoa in mice are still immotile after incubation into human tubal fluid (HTF) medium (Turner, 2006). This may suggest that a large proportion of spermatozoa leaving the testicles are in fact defective. On the other hand, reduced motility may also reflect inadequate epididymal maturation events. A long sperm storage period, observed in sexually inactive or older men, is also associated with reduced motility due to senescence of spermatozoa in the cauda epididymis (Turner, 2008).
In addition, Correa-Perez, Fernandez-Pelegrina, Aslanis, and Zavos (2004) have suggested that an abnormal epididymal sperm storage capacity could result in complete absence of motility as well as reduced viability that is so called necrozoospermia.

\section{3 | Sperm morphology}

Under the influence of epididymal secretions, spermatozoa undergo morphological remodelling, in particular, formation of a condensed acrosome and reorientation of the sperm head and tail (Dun, Aitken, \& Nixon, 2012).

The location and migration pattern of cytoplasmic droplet are a characteristic feature of sperm maturation (Cooper, 2011). During sperm transit through the epididymis, a cytoplasmic residue is located at the anterior region of the mid-piece of spermatozoa as a cytoplasmic droplet (Hermo, Pelletier, Cyr, \& Smith, 2010). In most mammalians, the migration of this cytoplasmic droplet along the sperm flagellum and finally its loss is observed during sperm transport to the cauda epididymis. The cytoplasmic droplet is not just a residue as it has to play significant roles for the continued maturation of epididymal spermatozoa. These include osmoadaptation by permitting water to enter or exit the cell (Chen et al., 2011) and providing energy for continued maturation (Yuan, Zheng, Zheng, \& Yan, 2013). The presence of large amounts of cytoplasm around the mid-piece of ejaculated spermatozoa is considered a major abnormality (Rengan, Agarwal, van der Linde, du Plessis, \& S., 2012) and reflects mainly a diminished sperm maturity (Gergely et al., 1999). In transgenic mice, the presence of a cytoplasmic droplet at the neck of ejaculated spermatozoa is associated with infertility, because these spermatozoa fail to maintain their volume upon osmotic challenge in the female genital tract (Cooper, Yeung, Wagenfeld, et al., 2004). Excessive residual cytoplasm is observed in spermatozoa from men with varicocele (Zini, Defreitas, Freeman, Hechter, \& Jarvi, 2000), smokers (Mak et al., 2000) and men with high levels of DNA fragmentation (Fischer, Willis, \& Zini, 2003). It may also indicate abnormal maturation because of defective spermiogenesis (Cooper, Yeung, Fetic, Sobhani, \& Nieschlag, 2004).

A number of gradual structural changes towards normal shape of spermatozoa are observed during epididymal passage, such as acrosomal reshaping, nuclear chromatin condensation, changes in some tail organelles, changes in the plasma membrane and fusion epididymosomes (Dun et al., 2012; Toshimori, 2003). Thus, any sperm morphological defect may be correlated with inadequate epididymal functional maturation and subsequent storage (Robaire et al., 2006).

On the other hand, the decrease in the percentage of morphologically abnormal spermatozoa in the epididymis as compared to abnormalities of testicular origin (Axnér, Linde-Forsberg, \& Einarsson, 1999) is also thought to be due to the ability of the epididymis in recognition and elimination of a morphologically abnormal spermatozoon (Varesi, Vernocchi, Faustini, \& Luvoni, 2013). Although there are different mechanisms such as phagocytosis, dissolution by ubiquitination and degradation via other proteins were 
proposed to explore such a phenomenon, and there is no evidence to support the ability of the epididymis in removal of abnormal spermatozoa (Robaire et al., 2006).

In contrast, the presence of a high proportion of sperm anomalies may indicate a disturbance of epididymal physiology (Kathrins, 2017). In the mouse model, alterations in ion and fluid transporters within the epididymis result in significant changes in the luminal fluid composition. Furthermore, abnormal water reabsorption is associated with abnormal sperm morphology. As a result, morphologically abnormal spermatozoa are leaving the testis (Hess, 1998). For example, epididymal hypo-osmolality in mouse leads to a decreased rate of fluid transport and subsequent dilution of the downstream luminal fluid. This further results in the presence of two major morphological defects: spontaneous acrosome reactions and severe flagellar coiling (Joseph, Shur, Ko, Chambon, \& Hess, 2010). Thus, sperm morphology could be a biophysical marker of sperm maturity (GutiérrezReinoso \& García-Herreros, 2016).

\section{4 | Oxidative stress and DNA fragmentation}

During the period of transit through and storage in the epididymis, spermatozoa are at risk of attacks by reactive oxygen species (ROS) due to the extraordinary high amount of polyunsaturated fatty acids in their plasma membrane (Vernet, Aitken, \& Drevet, 2004). If spermatozoa are exposed to excessive levels of ROS then their fertilising capacity and genetic integrity could be compromised directly or indirectly through many different mechanisms (Elbashir et al., 2018; Sakkas \& Alvarez, 2010). However, microenvironment associated with mammalian spermatozoa as they transit the epididymis utilises powerful, sophisticated enzymatic and nonenzymatic strategies to control ROS generation and recycling. Some nonenzymatic molecules that present during epididymal transit possess intrinsic radical scavenging activity such as $\alpha$-tocopherol, ascorbic acid, uric acid, glutathione (Halliwell \& Gutteridge, 1989), pyruvate (de Lamirande \& Gagnon, 1992), taurine, hypotaurine and albumin (Alvarez \& Storey, 1983). Moreover, different enzymes are present within the epididymis such as glutathione peroxidase, catalase, superoxide dismutase and indoleamine dioxygenase that possess the ability to metabolise hydroperoxides and protamine thiol oxidation, in addition to serving as an antioxidant protector (Vernet et al., 2004).

Disturbed epididymal maturation results in a large proportion of immature spermatozoa, which produce high levels of ROS (Sanocka \& Kurpisz, 2004). The epithelial cells from the epididymis may also produce hydroxyl radical or nitric oxides that results in generation of ROS (Ollero et al., 2001). When generation of ROS exceeds recycling and/or when there is failure of all the systems, eukaryotic cells have evolved to fight the inherent dangerous by-products of oxygen consumption, this directly induces oxidative stress (OS) leading to one major threat for sperm cells is oxidative injury. Current evidence has shown that spermatozoa as well as male infertility are impaired by OS. The effect of OS that is directly related to DNA damage to human spermatozoa could also be linked to a wide range of adverse clinical outcomes including compromised embryonic development, increase incidence of miscarriage and morbidity in the offspring, including childhood cancer (Chabory et al., 2009; Salah et al., 2018).

Higher DNA fragmentation in the caudal epididymal and ejaculated spermatozoa compared with testicular spermatozoa or spermatozoa from the corpus and caput epididymis was previously reported (Ollero et al., 2001). Elevated scrotal temperature or adverse environmental factors can directly impair the cauda epididymis environment and thereby induce ROS-DNA damage through the activation of sperm endogenous caspases and endonucleases (Rubes, Selevan, Sram, Evenson, \& Perreault, 2007). In addition, long storage periods of densely packed spermatozoa in the cauda increase the exposure period of spermatozoa to ROS and thereby increase the ROS-induced DNA damage (Sabeti, Pourmasumi, Rahiminia, Akyash, $\&$ Talebi, 2016). Hence, the epididymis is playing a significant role in restricting oxidative stress against spermatozoa through enzymatic and nonenzymatic defence mechanisms. In rats, $\gamma$-glutamyl transpeptidase present in the lumen of the proximal region of the epididymis regulates the levels of glutathione and taurine, which protect spermatozoa against ROS (Hinton, Palladino, Mattmueller, Bard, \& Good, 1991). Thus, compromised epididymal integrity is associated with a reduced antioxidant activity and increase in sperm DNA fragmentation (Watanabe et al., 2009).

\subsection{Debris and germ cells}

In normal adult rats, very few sloughed germ cells or cellular debris is present in the epididymal lumen. Germ cells or cellular debris is mainly produced from the testis, and their increased concentration in seminal fluid may be secondary to disturbed spermatogenesis (De Grava Kempinas \& Klinefelter, 2014). However, structural alterations in the epididymal epithelium secondary to direct toxicity can cause sloughing of principal cells into the epididymal lumen (De Andrade, Oliva, Klinefelter, \& De Grava Kempinas, 2006). In old men, the functional integrity of the blood-epididymis barrier may be altered, resulting in leaking of the debris of immature germ cells into the luminal fluid (Levy \& Robaire, 1999). Thus, epididymis-specific proteins, such as CRISP, RABP or clusterin, may provide a useful diagnostic tool to distinguish the origin of the cell debris, either testicular disorder or epididymal toxicity (De Grava Kempinas \& Klinefelter, 2014).

\section{6 | Leucocytes}

Leukocytospermia is the most common cause of male infertility ( $\mathrm{Li}$ \& Liu, 2006). Some studies showed that the presence of leucocytes in the semen is almost conjugated with decreased sperm motility, decreased number of normal sperm forms and impaired sperm function (Lackner, Agarwal, Mahfouz, du Plessis, \& Schatzl, 2010). An elevated seminal leucocyte count may reflect a genital tract infection or inflammatory disorder. The distribution, origin and role of 
leucocytes in semen are still controversial (Li \& Liu, 2006); however, it appears that most leucocytes may come from the epididymis as they are absent after vasectomy (Wolff, 1995). Genital tract infections are often preceded and accompanied by colonisation of the urethra or urine by pathogens, from which infection can affect the epididymis through the vas deferens (Bar-Chama \& Fisch, 1993).

\section{7 | PROSPECTIVE}

Despite considerable progress made in recent years, there are still many unresolved questions concerning the molecular and biochemical mechanisms that regulate the maturation process of spermatozoa in the epididymis. Since the isolation of various different epididymal cell types has not yet succeeded, our knowledge of actual functions of these different cells is still unclear. Little is known about the different levels of expression of various proteins within the principal cells as well as about the aspects of the cauda epididymal fluid that keep spermatozoa dormant and functional for protracted time periods. In addition, the changes in composition of luminal fluids along the fertile and infertile human epididymis still have to be identified (Jones \& Dacheux, 2007). Many reasons for epididymal dysfunction will remain unknown until the critical markers of epididymal function and the underlying regulatory mechanisms of sperm maturation are identified.

Data obtained using laboratory species about epididymal functions and structure should be extrapolated to humans with caution. Data from a long-term collaboration with local organ transplantation programme by Sullivan, Légaré, Lamontagne-Proulx, Breton, and Soulet (2019) showed that the human epididymis is peculiar when compared to laboratory animals. They found that there is no apparent initial segment and the proximal region is occupied by efferent ducts with a histology and cellular signature distinct from the adjacent caput epididymis segment. Furthermore, there is no segmentation in the first third portion of the human epididymis other than the efferent ducts and the caput segment. In addition, the distal part of the epididymis shows some histological variations, but appears quite similar with regard to gene expression profiling.

Well-designed studies on human epididymal functions are currently lacking. Most of the studies that provide information about the human epididymis have been performed with laboratory animals such as rats and the results were extrapolated to the human and other mammals. The lack of human epididymal tissue suitable for such studies is a major hurdle to fully understand the molecular and biochemical pathways. Since the epididymis is a single, highly coiled tube, it is very difficult to be biopsied. On the other hand, surgical epididymectomy is an extremely rare condition, in particular in men at reproductive age. Therefore, most of available studies on human epididymis have been performed with tissues from older men who have undergone therapeutic orchiectomy for prostate cancer. Tissues may also be extirpated from elderly men with testicular cancer.
Another occasional source of human epididymal tissue is from diseased men. Such tissue, however, cannot be considered normal because of its exposure to different medical treatments that interfere with the endocrine, paracrine and lumicrine signalling of the epididymis. Moreover, there are time limitations with the retrieval of the tissue since the tissue degenerates after death as well ethical issues that have to be considered.

\section{8 | CONCLUSION}

Ions, organic solutes and proteins secreted under androgenic control vary from one segment to the other along the epididymal tube. Their contribution modifies the male gamete in a sequential maturation process, resulting in fully fertilisation-competent spermatozoa that are stored safely in the cauda epididymis. Epididymal dysfunction as a result of physiological, physical and/or pathological disorders affects sperm quality and function and may subsequently affect fertility. Analysis of the semen quality could therefore reveal important information about sperm maturation and storage functions of the epididymis. Although significant progress has been made over the past years to increase the understanding of post-testicular sperm maturation, there is still only limited knowledge regarding the exact regulatory mechanisms that allow spermatozoa to attain full functional competence.

\section{CONFLICT OF INTEREST}

The authors have nothing to declare.

\section{ORCID}

Yasmin Magdi iD https://orcid.org/0000-0003-4804-6879

Ralf Henkel (iD https://orcid.org/0000-0003-1128-2982

Ashok Agarwal iD https://orcid.org/0000-0003-0585-1026

\section{REFERENCES}

Abella, D. F., Da Costa, M., Guérin, Y., \& Dacheux, J. L. (2015). Fertility of undiluted ram epididymal spermatozoa stored for several days at $4^{\circ} \mathrm{C}$. Animal, 9(2), 313-319. https://doi.org/10.1017/S175173111 4002109

Adamkovicova, M., Toman, R., Cabaj, M., Massanyi, P., Martiniakova, M., Omelka, R., ... Duranova, H. (2014). Effects of subchronic exposure to cadmium and diazinon on testis and epididymis in rats. The Scientific World Journal, https://doi.org/10.1155/2014/632581

Agre, P., King, L. S., Yasui, M., Guggino, W. B., Ottersen, O. P., Fujiyoshi, Y., ... Nielsen, S. (2002). Aquaporin water channels-from atomic structure to clinical medicine. The Journal of Physiology, 542, 3-16. https://doi.org/10.1113/jphysiol.2002.020818

Alvarez, J. G., \& Storey, B. T. (1983). Taurine, hypotaurine, epinephrine and albumin inhibit lipid peroxidation in rabbit spermatozoa and protect against loss of motility. Biology of Reproduction, 29, 548-555. https://doi.org/10.1095/biolreprod29.3.548

Amann, R. P., Hammerstedt, R. H., \& Veeramachaneni, D. N. (1993). The epididymis and sperm maturation: A perspective. Reproductive Fertility and Development, 5(4), 361-381. https://doi.org/10.1071/ RD9930361

Axnér, E., Linde-Forsberg, C., \& Einarsson, S. (1999). Morphology and motility of spermatozoa from different regions of the epididymal 
duct in the domestic cat. Theriogenology, 52, 767-778. https://doi. org/10.1016/S0093-691X(99)00170-3

Badr, Y. A. A., Motlagh, R. S., \& Sepehran, E. (2015). Bilateral isolated epididymal agenesis in a 32 year old man. International Brazilian Journal of Urology, 41(2), 379-381. https://doi.org/10.1590/S1677-5538. IBJU.2015.02.28

Bar-Chama, N., \& Fisch, H. (1993). Infection and pyospermia in male infertility. World Journal of Urology, 11(2), 76-81. https://doi.org/10.1007/ BF00182033

Barsoum, I., \& Yao, H. H. (2006). The road to maleness: From testis to Wolffian duct. Trends in Endocrinology and Metabolism: TEM, 17(6), 223-228. https://doi.org/10.1016/j.tem.2006.06.009

Bedford, J. M. (1978). Anatomical evidence for the epididymis as the prime mover in the evolution of the scrotum. American Journal of Anatomy, 152, 483-507. https://doi.org/10.1002/aja.1001520404

Bedford, J. M. (1994). The status and the state of the human epididymis. Human Reproduction Update, 9, 2187-2199. https://doi.org/10.1093/ oxfordjournals.humrep.a138416

Belleannee, C., Labas, V., Teixeira-Gomes, A. P., Gatti, J. L., Dacheux, J. L., \& Dacheux, F. (2011). Identification of luminal and secreted proteins in bull epididymis. Journal of Proteomics, 74, 59-78. https://doi. org/10.1016/j.jprot.2010.07.013

Benoit, J. (1926). Recherches anatomiques, cytologiques et histophysiologiques sur les voies excrétrices du testicule chez les mammifères. Archives D'anatomie, D'histologie Et D'embryologie, 5, 173-412.

Breton, S., Ruan, Y. C., Park, Y. J., \& Kim, B. (2016). Regulation of epithelial function, differentiation, and remodeling in the epididymis. Asian Journal of Andrology, 18(1), 3-9. https://doi. org/10.4103/1008-682X.165946

Brooks, D. E. (1987). Developmental expression and androgenic regulation of the mRNA for major secretory proteins of the rat epididymis. Molecular Cell Endocrinology, 53, 59-66. https://doi. org/10.1016/0303-7207(87)90192-4

Chabory, E., Damon, C., Lenoir, A., Kauselmann, G., Kern, H., Zevnik, B., ... Vernet, P. (2009). Epididymis seleno-independent glutathione peroxidase 5 maintains sperm DNA integrity in mice. The Journal of Clinical Investigation, 119(7), 2074-2085. https://doi.org/10.1172/JCI38940

Chauvin, T. R., \& Griswold, M. D. (2004). Androgen-regulated genes in the murine epididymis. Biology of Reproduction, 71, 560-569.

Chen, Q., Peng, H., Lei, L., Zhang, Y., Kuang, H., Cao, Y., ... Duan, E. (2011). Aquaporin3 is a sperm water channel essential for postcopulatory sperm osmoadaptation and migration. Cell Research, 21(6), 922-933. https://doi.org/10.1038/cr.2010.169

Cheuk, B. L., Leung, P. S., Lo, A. C., \& Wong, P. Y. (2000). Androgen control of cyclooxygenase expression in the rat epididymis. Biology of Reproduction, 63, 775-780.

Chitra, K. C., Manogem, E. M., Vardhanan Shibu, Y., Sebastian, C. D., \& Jayakumar, K. (2011). Testicular and epididymal toxicity of carbaryl in Sprague-Dawley strain rats. Journal of Advanced Laboratory Research in Biology, 2(2), 30-34.

Cooper, T. G. (2011). The epididymis, cytoplasmic droplets and male fertility. Asian Journal of Andrology, 13(1), 130-138. https://doi. org/10.1038/aja.2010.97

Cooper, T. G., Yeung, C. H., Fetic, S., Sobhani, A., \& Nieschlag, E. (2004). Cytoplasmic droplets are normal structures of human sperm but are not well preserved by routine procedures for assessing sperm morphology. Human Reproduction, 19(10), 2283-2288. https://doi. org/10.1093/humrep/deh410

Cooper, T. G., Yeung, C. H., Wagenfeld, A., Nieschlag, E., Poutanen, M., Huhtaniemi, I., \& Sipilä, P. (2004). Mouse models of infertility due to swollen spermatozoa. Molecular Cell Endocrinology, 216(1-2), 55-63. https://doi.org/10.1016/j.mce.2003.10.076

Cornwall, G. A. (2009). New insights into epididymal biology and function. Human Reproduction Update, 15(2), 213-227. https://doi. org/10.1093/humupd/dmn055
Cornwall, G. A., \& Horsten, H. H. (2007). Sperm maturation in the epididymis: Role of segment-specific micro environments. In D. T. Carrell (Ed.), The genetics of male infertility (pp. 1-337). Totowa, NJ: Humana Press Inc.

Correa-Perez, J. R., Fernandez-Pelegrina, R., Aslanis, P., \& Zavos, P. M. (2004). Clinical management of men producing ejaculates characterized by high levels of dead sperm and altered seminal plasma factors consistent with epididymal necrospermia. Fertility Sterility, 81, 11481150. https://doi.org/10.1016/j.fertnstert.2003.09.047

Cosentino, M. J., \& Cockett, A. T. (1986). Structure and function of the epididymis. Urological Research., 14(5), 229-240.

Creasy, D. M. (2001). Pathogenesis of male reproductive toxicity. Toxicologic Pathology, 29(1), 64-76. https://doi.org/10.1080/01926 2301301418865

Da Silva, N., Piétrement, C., Brown, D., \& Breton, S. (2006). Segmental and cellular expression of aquaporins in the male excurrent duct. Biochimica Et Biophysica Acta, 1758(8), 1025-1033. https://doi. org/10.1016/j.bbamem.2006.06.026

Dacheux, J. L., \& Dacheux, F. (2013). New insights into epididymal function in relation to sperm maturation. Reproduction, 147(2), 27-42. https://doi.org/10.1530/REP-13-0420

Dacheux, J. L., \& Paquignon, M. (1980). Relations between the fertilizing ability, motility and metabolism of epididymal spermatozoa. Reproduction Nutrition Development, 20(4A), 1085-1099. https://doi. org/10.1051/rnd:19800617

De Andrade, S. F., Oliva, S. U., Klinefelter, G. R., \& De Grava Kempinas, W. (2006). Epididymis-specific pathologic disorders in rats exposed to gossypol from weaning through puberty. Toxicologic Pathology, 34, 730-737. https://doi.org/10.1080/01926230600932455

De Grava Kempinas, W., \& Klinefelter, G. R. (2014). Interpreting histopathology in the epididymis. Spermatogenesis, 4(2), e979114. https:// doi.org/10.4161/21565562.2014.979114

de Lamirande, E., \& Gagnon, C. (1992). Reactive oxygen species and human spermatozoa. Part II. Depletion of adenosine triphosphate plays an important role in the inhibition of sperm motility. Journal of Andrology, 13, 379-386.

Domeniconi, R. F., Souza, A. C., Xu, B., Washington, A. M., \& Hinton, B. T. (2016). Is the epididymis a series of organs placed side by side? Biology of Reproduction, 95(1), 10. https://doi.org/10.1095/biolr eprod.116.138768

Dubé, E., Chan, P. T., Hermo, L., \& Cyr, D. G. (2007). Gene expression profiling and its relevance to the blood-epididymal barrier in the human epididymis. Biology of Reproduction, 76, 1034-1044.

Dubé, E., \& Cyr, D. G. (2012). The blood-epididymis barrier and human male fertility. Advances in Experimental Medicine Biology, 763, 218-2136.

Dun, M. D., Aitken, R. J., \& Nixon, B. (2012). The role of molecular chaperones in spermatogenesis and the post-testicular maturation of mammalian spermatozoa. Human Reproduction Update, 18, 420-435. https://doi.org/10.1093/humupd/dms009

Dyson, A. L., \& Orgebin-Crist, M. C. (1973). Effect of hypophysectomy, castration and androgen replacement upon the fertilizing ability of rat epididymal spermatozoa. Endocrinology, 93, 391-402. https://doi. org/10.1210/endo-93-2-391

Elbashir, S., Magdi, Y., Rashed, A., Ibrahim, M. A., Edris, Y., \& Abdelazizd, A. M. (2018). Relationship between sperm progressive motility and DNA integrity in fertile and infertile men. Middle East Fertility Society Journal, 23(3), 195-198. https://doi.org/10.1016/j.mefs.2017.12.002

Fahmy, M. A. (Ed.) (2015). Rare congenital genitourinary anomalies: An illustrated reference guide. Berlin, Heidelberg: Springer-Verlag.

Fan, X. P., \& Robaire, B. (1998). Orchiectomy induces a wave of apoptotic cell death in the epididymis. Endocrinology, 139, 2128-2136.

Fang, F., Ni, K., Cai, Y., Zhao, Q., Shang, J., Zhang, X., ... Xiong, C. (2017). Busulfan administration produces toxic effects on epididymal morphology and inhibits the expression of ZO-1 and vimentin in the 
mouse epididymis. Bioscience Reports, 37(6), BSR20171059. https:// doi.org/10.1042/BSR20171059

Favorito, L. A., Riberio Julio-Junior, H., \& Sampaio, F. J. (2017). Relationship between Undescended Testis Position and Prevalence of Testicular Appendices, Epididymal Anomalies, and Patency of Processus Vaginalis. BioMed research international, 2017, 5926370.

Fawcett, D. W., \& Hoffer, A. P. (1979). Failure of exogenous androgen to prevent regression of the initial segments of the rat epididymis after efferent duct ligation or orchidectomy. Biology of Reproduction, 20, 162-181.

Fibbi, B., Filippi, S., Morelli, A., Vignozzi, L., Silvestrini, E., Chavalmane, A., ... Maggi, M. (2009). Estrogens regulate humans and rabbit epididymal contractility through the RhoA/Rho-kinase pathway. The Journal of Sexual Medicine, 6, 2173-2186. https://doi. org/10.1111/j.1743-6109.2009.01282.x

Filippi, S., Luconi, M., Granchi, S., Vignozzi, L., Bettuzzi, S., Tozzi, P., ... Maggi, M. (2002). Estrogens, but not androgens, regulate expression and functional activity of oxytocin receptor in rabbit epididymis. Endocrinology, 143(11), 4271-4280. https://doi.org/10.1210/ en.2002-220384

Filippi, S., Morelli, A., Vignozzi, L., Vannelli, G. B., Marini, M., Ferruzzi, P., ... Maggi, M. (2005). Oxytocin mediates the estrogen-dependent contractile activity of endothelin-1 in human and rabbit epididymis. Endocrinology, 146, 3506-3517. https://doi.org/10.1210/ en.2004-1628

Fischer, M. A., Willis, J., \& Zini, A. (2003). Human sperm DNA integrity: Correlation with sperm cytoplasmic droplets. Urology, 61, 207-211. https://doi.org/10.1016/S0090-4295(02)02098-8

Fouchecourt, S., Metayer, S., Locatelli, A., Dacheux, F., \& Dacheux, J. L. (2000). Stallion epididymal fluid proteome: Qualitative and quantitative characterization; secretion and dynamic changes of major proteins. Biology of Reproduction, 62, 1790-1803.

Garcia, P. V., Barbieri, M. F., Perobelli, J. E., Consonni, S. R., Mesquita Sde, F., Kempinas Wde, G., \& Pereira, L. A. (2012). Morphometricstereological and functional epididymal alterations and a decrease in fertility in rats treated with finasteride and after a 30-day post-treatment recovery period. Fertility and Sterility, 97(6), 1444-1451. https:// doi.org/10.1016/j.fertnstert.2012.03.025

Gergely, A., Kovanci, E., Senturk, L., Cosmi, E., Vigue, L., \& Huszar, G. (1999). Morphometric assessment of mature and diminished-maturity human spermatozoa: Sperm regions that reflect differences in maturity. Human Reproduction, 14, 2007-2014. https://doi. org/10.1093/humrep/14.8.2007

Gervasi, M. G., \& Visconti, P. E. (2017). Molecular changes and signaling events occurring in spermatozoa during epididymal maturation. Andrology, 5(2), 204-218. https://doi.org/10.1111/andr.12320

Geyer, C. B., Kiefer, C. M., Yang, T. P., \& McCarrey, J. R. (2004). Ontogeny of a demethylation domain and its relationship to activation of tissue-specific transcription. Biology of Reproduction, 71, 837-844.

Girouard, J., Frenette, G., \& Sullivan, R. (2011). Comparative proteome and lipid profiles of bovine epididymosomes collected in the intraluminal compartment of the caput and cauda epididymitis. International Journal of Andrology, e475-e486.

Guiton, R., Henry-Berger, J., \& Drevet, J. R. (2013). The immunobiology of the mammalian epididymis: The black box is now open!. Basics of Clinical Andrology, 23, 8. https://doi.org/10.1186/2051-4190-23-8

Gutiérrez-Reinoso,M.A., \&García-Herreros, M. (2016). Normozoospermic versus teratozoospermic domestic cats: Differential testicular volume, sperm morphometry, and subpopulation structure during epididymal maturation. Asian Journal of Andrology, 18(6), 871-878.

Hadziselimovic, F., \& Herzog, B. (1983). The development and descent of the epididymis. European Journal of Pediatrics, 152(2), 6-9.
Halliwell, B., \& Gutteridge, J. M. C. (1989). Free radicals in biology and medicine, 2nd ed. Oxford, UK: Clarendon Press.

Hamzeh, M., \& Robaire, B. (2011). Androgens activate mitogen-activated protein kinase via epidermal growth factor receptor/insulin-like growth factor 1 receptor in the mouse PC-1 cell line. Journal of Endocrinology, 209, 55-64. https://doi.org/10.1530/JOE-10-0223

Han, C. H., \& Kang, S. H. (2002). Epididymal anomalies associated with patent processus vaginalis in hydrocele and cryptorchidism. Journal Korean Medical Science, 17, 660-662. https://doi.org/10.3346/ jkms.2002.17.5.660

Hedger, M. P. (2011). Immunophysiology and pathology of inflammation in the testis and epididymis. Journal of Andrology, 32, 625-640. https://doi.org/10.2164/jandrol.111.012989

Hermo, L., Pelletier, R. M., Cyr, D. G., \& Smith, C. E. (2010). Surfing the wave, cycle, life history, and genes/proteins expressed by testicular germ cells. Part 1: Background to spermatogenesis, spermatogonia, and spermatocytes. Microscopy Research and Technique, 73(4), 241-278.

Hermo, L., \& Robaire, B. (2002). Epididymis cell types and their function. In B. Robaire, \& B. T. Hinton (Eds.), The epididymis: From Molecules to clinical practice (pp. 81-102). New York, NY: Kluwer Academic/ Plenum Publishers.

Hess, R. A. (1998). Effects of environmental toxicants on the efferent ducts, epididymis and fertility. Journal of Reproduction and Fertility Supplement, 53, 247-259.

Hess, R. A., Bunick, D., Lee, K. H., Bahr, J., Taylor, J. A., Korach, K. S., \& Lubahn, D. B. (1997). A role for oestrogens in the male reproductive system. Nature, 390, 509-512. https://doi.org/10.1038/37352

Hinton, B. T., Galdamez, M. M., Sutherland, A., Bomgardner, D., Xu, B., Abdel-Fattah, R., \& Yang, L. (2011). How do you get six meters of epididymis inside a human scrotum? Journal of Andrology, 32(6), 558564. https://doi.org/10.2164/jandrol.111.013029

Hinton, B. T., Palladino, M. A., Mattmueller, D. R., Bard, D., \& Good, K. (1991). Expression and activity of gamma glutamyl transpeptidase in the rat epididymis. Molecular Reproduction and Development, 28, 40-46. https://doi.org/10.1002/mrd.1080280107

Hirsh, A. V., Dean, N. L., Mohan, P. J., Shaker, A. G., \& Bekir, J. S. (1996). Natural spermatoceles in irreversible obstructive azoospermiareservoirs of viable spermatozoa for assisted conception. Human Reproduction, 11(9), 1919-1922.

Huynh, P. N., Hikim, A. P., Wang, C., Stefonovic, K., Lue, Y. H., Leung, A., ... Swerdloff, R. S. (2000). Long-term effects of triptolide on spermatogenesis, epididymal sperm function, and fertility in male rats. Journal of Andrology, 21(5), 689-699.

Jelinsky, S. A., Turner, T. T., Bang, H. J., Finger, J. N., Solarz, M. K., Wilson, E., ... Johnston, D. S. (2007). The rat epididymal transcriptome: comparison of segmental gene expression in the rat and mouse epididymides. Biology of reproduction, 76(4), 561-570.

Johnson, L., \& Varner, D. D. (1988). Effect of daily spermatozoan production but not age on transit time of spermatozoa through the human epididymis. Biology of Reproduction, 39(4), 812-817.

Jones, R. C. (1999). To store or mature spermatozoa? The primary role of the epididymis. International Journal of Andrology, 22(2), 57-67. https://doi.org/10.1046/j.1365-2605.1999.00151.x

Jones, R. C., \& Dacheux, J. L. (2007). Physiology of the epididymis. In F. R. Kandeel, R. S. Swerdloff, \& J. L. Prior (Eds.), Male reproductive dysfunction. Boca Raton: CRC Press. https://doi.org/10.3109/97814 20018813

Joseph, A., Shur, B. D., Ko, C., Chambon, P., \& Hess, R. A. (2010). Epididymal hypo-osmolality induces abnormal sperm morphology and function in the estrogen receptor alpha knockout mouse. Biology of Reproduction, 82(5), 958-967.

Joseph, A., Yao, H., \& Hinton, B. T. (2009). Development and morphogenesis of the Wolffian/epididymal duct, more twists and turns. 
Developmental Biology, 325(1), 6-14. https://doi.org/10.1016/j. ydbio.2008.10.012

Kathrins, M. (2017). Original descriptions of the relationship between epididymal function and sperm morphology. Fertility and Sterility, 108(1), 45-46. https://doi.org/10.1016/j.fertnstert.2017.05.023

Kroovand, R. L., \& Perlmutter, A. D. (1981). Congenital anomalies of the Vas Deferens and epididymis. In: Kogan SJ, Hafez ESE, eds. Pediatric andrology. Clinics in andrology (vol. 7, pp. 173-180). Dordrecht, The Netherlands: Springer.

Lackner, J. E., Agarwal, A., Mahfouz, R., du Plessis, S. S., \& Schatzl, G. (2010). The association between leukocytes and sperm quality is concentration dependent. Reproductive Biology and Endocrinology, 5, 8-12. https://doi.org/10.1186/1477-7827-8-12

Lazarus, J. A., \& Marks, M. S. (1947). Anomalies associated with undescended testis. Complete separation of a partly descended epididymis and vas deferens and an abdominal testis. Journal of Urology, 57(3), 567-574.

Levine, N., \& Marsh, D. J. (1971). Micropuncture studies of the electrochemical aspects of fluid and electrolyte transport in individual seminiferous tubules, the epididymis and the vas deferens in rats. The Journal of Physiology, 213, 557-570. https://doi.org/10.1113/jphys iol.1971.sp009400

Levy, S., \& Robaire, B. (1999). Segment-specific changes with age in the expression of junctional proteins and the permeability of the blood-epididymis barrier in rats. Biology of Reproduction, 60, 1392-1401.

Li, J., \& Li, R. Z. (2006). Progress in leukocytospermia research. Zhonghua Nan Ke Xue, 12(8), 730-736.

Liu, X., \& Liu, F. (2015). In-depth mapping of human testicular and epididymal proteins and their functional association with spermatozoa. Molecular Medicine Reports, 12(1), 173-179. https://doi.org/10.3892/ mmr.2015.3435

Lythgoe, J. P. (1961). Failure of fusion of the testis and epididymis. British Journal of Urolology, 33, 80-81. https://doi.org/10.1111/j.1464410X.1961.tb11588.x

Mak, V., Jarvi, K., Buckspan, M., Freeman, M., Hechter, S., \& Zini, A. (2000). Smoking is associated with the retention of cytoplasm by human spermatozoa. Urology, 56, 463-466.

Maneely, R. B. (1959). Epididymal structure and function. A historical and critical review. Acta Zoologica, 40, 1-21. https://doi. org/10.1111/j.1463-6395.1959.tb00389.x

Marshall, F. F., \& Shermeta, D. W. (1979). Epididymal abnormalities associated with undescended testis. Journal of Urology, 121(3), 341-343. https://doi.org/10.1016/S0022-5347(17)56780-4

Marty, M. S., Chapin, R. E., Parks, L. G., \& Thorsrud, B. A. (2003) Development and maturation of the male reproductive system. Birth Defects Research Part B Developmental and Reproductive Toxicology, 68(2), 125-136. https://doi.org/10.1002/bdrb.10015

Mathieu, C., Guerin, J. F., Cognat, M., Lejeune, H., Pinatel, M. C., \& Lornage, J. (1992). Motility and fertilizing capacity of epididymal human spermatozoa in normal and pathological cases. Fertility and Sterility, 57, 871-876. https://doi.org/10.1016/S0015 -0282(16)54973-5

McCullough, R., Marshall, F. F., Berry, S. J., \& Detweiler, C. (1984). The influence of epididymal agenesis on the development and maturation of the testis: Experimental model and clinical correlations. Urological Research, 12, 165-170. https://doi.org/10.1007/BF00255916

Meistrich, M. L., Hughes, T. H., \& Bruce, W. R. (1975). Alteration of epididymal sperm transport and maturation in mice by oestrogen and testosterone. Nature, 258, 145-147. https://doi. org/10.1038/258145a0

Michel, V., Duan, Y., Stoschek, E., Bhushan, S., Middendorff, R., Young, J. M., ... Meinhardt, A. (2016). Uropathogenic Escherichia coli causes fibrotic remodelling of the epididymis. Journal of Pathology, 240, $15-24$.
Moore, H. D. (1998). Contribution of epididymal factors to sperm maturation and storage. Andrologia, 30(4-5), 233-239. https://doi. org/10.1111/j.1439-0272.1998.tb01165.x

Murashima, A., Xu, B., \& Hinton, B. T. (2015). Understanding normal and abnormal development of the Wolffian/epididymal duct by using transgenic mice. Asian Journal of Andrology, 17(5), 749-755.

Nixon, B., De luliis, G. N., Hart, H. M., Zhou, W., Mathe, A., Bernstein, I. R., ... Dun, M. D. (2019). Proteomic profiling of mouse epididymosomes reveals their contributions to post-testicular sperm maturation. Molecular and Cellular Proteomics, 18, S91-S108. https://doi. org/10.1074/mcp.RA118.000946

O'Hara, L., Welsh, M., Saunders, P. T. K., \& Smith, L. B. (2011). Androgen receptor expression in the caput epididymal epithelium is essential for development of the initial segment and epididymal spermatozoa transit. Endocrinology, 152(2), 718-729. https://doi.org/10.1210/ en.2010-0928

Ola, B., Afnan, M., Papaioannou, S., Sharif, K., Bjorndahl, L. et al (2003). Accuracy of sperm-cervical mucus penetration tests in evaluating sperm motility in semen: A systematic quantitative review. Human Reproduction, 18, 1037-1046. https://doi.org/10.1093/humrep/ deg209

Ollero, M., Gil-Guzman, E., Lopez, M. C., Sharma, R. K., Agarwal, A., Larson, K., ... Alvarez, J. G. (2001). Characterization of subsets of human spermatozoa at different stages of maturation: Implications in the diagnosis and treatment of male infertility. Human Reproduction, 16, 1912-1921. https://doi.org/10.1093/humrep/16.9.1912

Paunescu, T. G., Shum, W. W., Huynh, C., Lechner, L., Goetze, B., Brown, D., \& Breton, S. (2014). High-resolution helium ion microscopy of epididymal epithelial cells and their interaction with spermatozoa. Molecular Human Reproduction, 20, 929-937. https://doi. org/10.1093/molehr/gau052

Ramesh, A., Inyang, F., Lunstra, D. D., Niaz, M. S., Kopsombut, P., Jones, K. M., ... Archibong, A. E. (2008). Alteration of fertility endpoints in adult male F-344 rats by subchronic exposure to inhaled benzo(a) pyrene. Experimental and Toxicologic Pathology, 60(4-5), 269-280. https://doi.org/10.1016/j.etp.2008.02.010

Reilly, J. N., McLaughlin, E. A., Stanger, S. J., Anderson, A. L., Hutcheon, K., Church, K., ... Nixon, B. (2016). Characterisation of mouse epididymosomes reveals a complex profile of microRNAs and a potential mechanism for modification of the sperm epigenome. Scientific Reports, 23(6), 31794.

Rengan, A. K., Agarwal, A., van der Linde, M., \& du Plessis, S. S. (2012). An investigation of excess residual cytoplasm in human spermatozoa and its distinction from the cytoplasmic droplet. Reproductive Biology and Endocrinology, 10, 92. https://doi.org/10.1186/1477-7827-10-92

Robaire, B., \& Hamzeh, M. (2011). Androgen action in the epididymis. Journal of Andrology, 32(6), 592-599. https://doi.org/10.2164/jandr ol.111.014266

Robaire, B., \& Hinton, B. T. (2015). The epididymis. In T. M. Plant, \& A. J. Zeleznik (Eds.), Knobil and Neill's physiology of reproduction (pp. 691771). New York, NY: Elsevier.

Robaire, B., Hinton, B. T., \& Orgebin-Crist, M. C. (2006). The epididymis. In J. D. Neill (Ed.), Knobil and Neill's physiology of reproduction (3rd ed, pp. 1071-1148). San Diego, CA: Elsevier/Academic Press.

Rosenberg, V., \& Urca, I. (1972). A rare congenital malformation: Nonunion of the testicle with the epididymis and the spermatic duct. British Journal of Urolology, 44(4), 499-502. https://doi.org/10.1111/ j.1464-410X.1972.tb10113.x

Rowley, M. J., Teshima, F., \& Heller, G. G. (1970). Duration of transit of spermatozoa through the human male ductular system. Fertility and Sterility, 21(5), 390-396.

Rubes, J., Selevan, S. G., Sram, R. J., Evenson, D. P., \& Perreault, S. D. (2007). GSTM1 genotype influences the susceptibility of men to sperm DNA damage associated with exposure to air pollution. Mutation Research, 625, 20-28. https://doi.org/10.1016/j.mrfmmm.2007.05.012 
Sabeti, P., Pourmasumi, S., Rahiminia, T., Akyash, F., \& Talebi, A. R. (2016). Etiologies of sperm oxidative stress. International Journal of Reproductive, bioMedicine,14(4), 231-240. https://doi.org/10.29252/ ijrm.14.4.231

Sakkas, D., \& Alvarez, J. G. (2010). Sperm DNA fragmentation: Mechanisms of origin, impact on reproductive outcome, and analysis. Fertility and Sterility, 93(4), 1027-1036. https://doi.org/10.1016/j. fertnstert.2009.10.046

Salah, E., Magdi, Y., Rashed, A., Ibrahim, M. A., Edris, Y., \& Abdelaziz, A. (2018). Middle East Fertility Society Journal, 23(3), 195-198.

Sanocka, D., \& Kurpisz, M. (2004). Reactive oxygen species and sperm cells. Reproductive Biology and Endocrinology, 2, 12.

Schorr-Lenz, A. M., Alves, J., Henckes, N. A., Seibel, P. M., Benham, A. M., \& Bustamante-Filho, I. C. (2016). GnRH immunization alters the expression and distribution of protein disulfide isomerases in the epididymis. Andrology, 4(5), 957-963. https://doi.org/10.1111/andr.12205

Scorer, C. G., \& Farrington, G. H. (1972). Congenital Deformities of the Testis and Epididymis. Postgraduate Medical Journal, 48, 563-569.

Sharma, U., Sun, F., Conine, C. C., Reichholf, B., Kukreja, S., Herzog, V. A., ... Rando, O. J. (2018). Small RNAs are trafficked from the epididymis to developing mammalian sperm. Developmental Cell, 46(4), 481-494. https://doi.org/10.1016/j.devcel.2018.06.023

Singh, R., Hamada, A. J., Bukavina, L., \& Agarwal, A. (2012). Physical deformities relevant to male infertility. Nature Reviews Urology, 9(3), 156-174. https://doi.org/10.1038/nrurol.2012.11

Skerget, S., Rosenow, M. A., Petritis, K., \& Karr, T. L. (2015). Sperm proteome maturation in the mouse epididymis. PLoS One, 10(11), e0140650. https://doi.org/10.1371/journal.pone.0140650

Snyder, E. M., Small, C. L., Bomgardner, D., Xu, B., Evanoff, R., Griswold, M. D., \& Hinton, B. T. (2010). Gene expression in the efferent ducts, epididymis, and vas deferens during embryonic development of the mouse. Developmental Dynamics, 239(9), 2479-2491. https://doi. org/10.1002/dvdy.22378

Snyder, E. M., Small, C. L., Li, Y., \& Griswold, M. D. (2009). Regulation of gene expression by estrogen and testosterone in the proximal mouse reproductive tract. Biology of Reproduction, 81, 707-716.

Sonawane, T., Azaz, S., Hemant, K., \& Liji, T. (2019). Epididymal toxicity associated with vincristine treatment. Indian Journal of Pharmaceutical Sciences, 81(3), 514-520. https://doi.org/10.36468/pharmaceuticalsciences. 537

Sullivan, R. (2004). Male fertility markers, myth or reality. Animal Reproduction Science, 82, 341-347. https://doi.org/10.1016/j.anire prosci.2004.05.007

Sullivan, R., Légaré, C., Lamontagne-Proulx, J., Breton, S., \& Soulet, D. (2019). Revisiting structure/functions of the human epididymis. Andrology, 7(5), 748-757.

Sullivan, R., \& Mieusset, R. (2016). The human epididymis: Its function in sperm maturation. Human Reproduction Update, 22(5), 574-587. https://doi.org/10.1093/humupd/dmw015

Takahashi, O., \& Oishi, S. (2003). Testicular toxicity of dietarily or parenterally administered bisphenol $A$ in rats and mice. Food and Chemical Toxicology, 41(7), 1035-1044. https://doi.org/10.1016/S0278 -6915(03)00031-0

Takano, H., Abe, K., \& Ito, T. (1981). Changes in the mouse epididymis after ligation of the ductuli efferentes or proximal epididymal duct: Qualitative and quantitative histological studies. Kaibogaku Zasshi, 56(2), 79-90.

Toshimori, K. (2003). Biology of spermatozoa maturation: An overview with an introduction to this issue. Microscopy Research and Technique, 61, 1-6. https://doi.org/10.1002/jemt.10311

Trasler, J. M., \& Robaire, B. (1988). Effects of cyclophosphamide on selected cytosolic and mitochondrial enzymes in the epididymis of the rat. Journal of Andrology, 9(2), 142-152. https://doi. org/10.1002/j.1939-4640.1988.tb01026.x
Tulsiani, D. R., \& Abou-Haila, A. (2012). Biological processes that prepare mammalian spermatozoa to interact with an egg and fertilize it. Scientifica (Cairo), 2012, 607427. https://doi. org/10.6064/2012/607427

Turner, R. M. (2006). Moving to the beat: A review of mammalian sperm motility regulation. Reproduction Fertility and Development, 18, 2538. https://doi.org/10.1071/RD05120

Turner, T. T. (2008). De Graaf's thread: The human epididymis. Journal of Andrology, 3, 237-250. https://doi.org/10.2164/jandrol.107.004119

Turner, T. T., Bomgardner, D., Jacobs, J. P., \& Nguyen, Q. A. (2003). Association of segmentation of the epididymal interstitium with segmented tubule function in rats and mice. Reproduction, 125(6), 871-878. https://doi.org/10.1530/rep.0.1250871

Turner, T. T., Gleavy, J. L., \& Harris, J. M. (1990). Fluid movement in the lumen of the rat epididymis: Effect of vasectomy and subsequent vasovasostomy. Journal of Andrology, 11, 422-428.

Varesi, S., Vernocchi, V., Faustini, M., \& Luvoni, G. C. (2013). Morphological and acrosomal changes of canine spermatozoa during epididymal transit. Acta Veterinaria Scandinavica, 55(1), 17. https:// doi.org/10.1186/1751-0147-55-17

Verkman, A. S., \& Mitra, A. K. (2000). Structure and function of aquaporin water channels. The American Journal of Physiology: Renal Physiology, 278(1), F13-28.

Vernet, P., Aitken, R. J., \& Drevet, J. R. (2004). Antioxidant strategies in the epididymis. Molecular Cell Endocrinology, 216(1-2), 31-39. https:// doi.org/10.1016/j.mce.2003.10.069

Vidal, J. D., \& Whitney, K. M. (2014). Morphologic manifestations of testicular and epididymal toxicity. Spermatogenesis, 4(2), e979099.

Vignozzi, L., Filippi, S., Morelli, A., Luconi, M., Jannini, E., Forti, G., \& Maggi, M. (2010). Regulation of epididymal contractility during semen emission, the first part of the ejaculatory process: A role for estrogen. The Journal of Sexual Medicine, 5, 2010-2016.

Vohra, S., \& Morgentaler, A. (1997). Congenital anomalies of the vas deferens, epididymis, and seminal vesicles. Urology, 49, 313-321. https://doi.org/10.1016/S0090-4295(96)00433-5

Wallach, E. E., \& Wolff, H. (1995). The biologic significance of white blood cells in semen. Fertility and Sterility, 63, 1143-1157. https://doi. org/10.1016/S0015-0282(16)57588-8

Watanabe, M., Roussev, R., Ahlering, P., Sauer, R., Coulam, C., \& Jeyendran, R. S. (2009). Correlation between neutral alpha-glucosidase activity and sperm DNA fragmentation. Andrologia, 41(5), 316318. https://doi.org/10.1111/j.1439-0272.2009.00950.x

Witkin, S. S., Jeremias, J., Bongiovanni, A. M., \& Munoz, M. G. (1996). Immune regulation in the male genital tract. Infectious Disease in Obstetrics and Gynecology, 4, 131-135. https://doi.org/10.1002/ (SICI)1098-0997(1996)4:3<131:AID-IDOG5>3.0.CO;2-3

Wong, P. Y., \& Yeung, C. H. (1978). Absorptive and secretory functions of the perfused rat cauda epididymidis. The Journal of Physiology, 275, 13-26. https://doi.org/10.1113/jphysiol.1978.sp012174

Working, P. K., Bus, J. S., \& Hamm, T. E. (1985). Reproductive effects of inhaled methyl chloride in the male Fischer 344 rat. I. Mating performance and dominant lethal assay. Toxicology and Applied Pharmacology., 77, 133-143.

Xu, B., Washington, A. M., \& Hinton, B. T. (2014). PTEN signaling through RAF1 proto-oncogene serine/threonine kinase (RAF1)/ERK in the epididymis is essential for male fertility. Proceedings of the National Academy of Sciences of the United States of America, 111, 1864318648. https://doi.org/10.1073/pnas.1413186112

Yeung, C. H., Wang, K., \& Cooper, T. G. (2012). Why are epididymal tumors so rare? Asian Journal of Andrology, 14, 465-475.

Yuan, S., Zheng, H., Zheng, Z., \& Yan, W. (2013). Proteomic analyses reveal a role of cytoplasmic droplets as an energy source during epididymal sperm maturation. PLoS One, 8(10), e77466. https://doi. org/10.1371/journal.pone.0077466 
Zhou, W., De luliis, G. N., Dun, M. D., \& Nixon, B. (2018). Characteristics of the epididymal luminal environment responsible for sperm maturation and storage. Front Endocrinol (Lausanne)., 28, 9-59. https://doi. org/10.3389/fendo.2018.00059

Zhu, L. J., Hardy, M. P., Inigo, I. V., Huhtaniemi, I., Bardin, C. W., MooYoung, A. J. (2000). Effects of androgen on androgen receptor expression in rat testicular and epididymal cells: a quantitative immunohistochemical study. Biology of reproduction, 63(2), 368-376.

Zini, A., Defreitas, G., Freeman, M., Hechter, S., \& Jarvi, K. (2000). Varicocele is associated with abnormal retention of cytoplasmic droplets by human spermatozoa. Fertility and Sterility, 74, 461-464. https://doi.org/10.1016/S0015-0282(00)00703-2

How to cite this article: Elbashir S, Magdi Y, Rashed A, Henkel R, Agarwal A. Epididymal contribution to male infertility: An overlooked problem. Andrologia.

2021;53:e13721. https://doi.org/10.1111/and.13721 